\title{
P02.92. The effect of physical activity, obesity, and low vitamin D on all cause mortality in US adults
}

\author{
C Crespo $^{1 *}$, G Escutia-Dominguez ${ }^{1}$, E Smit $^{2}$, G Brodowicz $^{1}$, S Aden $^{1}$ \\ From International Research Congress on Integrative Medicine and Health 2012 \\ Portland, Oregon, USA. 15-18 May 2012
}

\section{Purpose}

To examine the effect of 25-hydroxyvitamin D (serum 25 $(\mathrm{OH}) \mathrm{D})$, body mass index and leisure time physical activity on all-cause mortality and determine the association between serum $25(\mathrm{OH}) \mathrm{D}$ and leisure time physical activity among US adults.

\section{Methods}

We used data from 16,285 adults 20 years and older who participated in a home interview and a mobile examination of the Third National Health and Nutrition Examination Survey (1988-1994) that were linked to National Death Index mortality files up to 2006. Physical activity categories included: Inactive (less than $1 / \mathrm{wk}$ ), Somewhat active (2-4 times/wk), and Active (5+/wk). Body mass index (BMI) included: Underweight $(<18.5)$, Normal weight (18.5-24.9), Overweight (25-29.9), and Obese (30+). Serum $25(\mathrm{OH}) \mathrm{D}$ were divided into quartiles, and quartile 1 or low levels included those with values of $\leq 50 \mathrm{nmol} / \mathrm{L}$. Cox proportional hazards were calculated using SAS and SUDAAN softwares to account for sampling weights of NHANES.

\section{Results}

In the final model we adjusted for age, sex, race/ethnicity, education, smoking status, region of the country, and presence of chronic diseases plus the three variables of interest: physical activity, body mass index, and serum $25(\mathrm{OH})$ D. Low serum vitamin D was a significant predictor of all cause mortality independent of physical activity and obesity status; and while being physically active 5 or more times a week had a protective effect $(R R=0.65,95$

${ }^{1}$ Portland State University, Portland, USA

Full list of author information is available at the end of the article
$\mathrm{CI}=0.58,0.74)$, obesity was not significantly related $(1.06$, $95 \mathrm{CI}=0.96-1.18)$ with all cause mortality.

\section{Conclusion}

We found that low Vitamin D and physical inactivity were independent risk factors for all-cause mortality whereas obesity was not an independent risk factor when adjusting for physical activity and serum Vitamin $\mathrm{D}$ levels. More research is needed to understand the role of adiposity in serum $25(\mathrm{OH}) \mathrm{D}$ metabolism.

\section{Author details}

${ }^{1}$ Portland State University, Portland, USA. ${ }^{2}$ Oregon State University, Corvallis, USA.

Published: 12 June 2012

doi:10.1186/1472-6882-12-S1-P148

Cite this article as: Crespo et al:: P02.92. The effect of physical activity, obesity, and low vitamin D on all cause mortality in US adults. BMC Complementary and Alternative Medicine 2012 12(Suppl 1):P148.

Submit your next manuscript to BioMed Central and take full advantage of:

- Convenient online submission

- Thorough peer review

- No space constraints or color figure charges

- Immediate publication on acceptance

- Inclusion in PubMed, CAS, Scopus and Google Scholar

- Research which is freely available for redistribution

C Biomed Central

2012 crespo et aliticensee BloMed Centrat Ltd

C 2012 Crespo et al; licensee BioMed Central Ltd. This is an Open Access article distributed under the terms of the Creative Commons Attribution License (http://creativecommons.org/licenses/by/2.0), which permits unrestricted use, distribution, and reproduction in any medium, provided the original work is properly cited. 